\title{
USAHATANI BUDIDAYA JAGUNG HIBRIDA VARIETAS BIMA 19-URI DI LAHAN SAWAH TADAH HUJAN KABUPATEN OGAN KOMERING ILIR SUMATERA SELATAN
}

\author{
Maya Dhania Sari*), Suparwoto1) \\ 1)Balai Pengkajian Teknologi Pertanian Sumatera Selatan \\ Jalan Kol. H. Burlian KM.6 No. 83 Palembang, Sumatera Selatan \\ Telp. 0711-410155 \\ "Email : mayadhaniasari@gmail.com
}

\begin{abstract}
South Sumatra Province has potential in developing maize farming, but farmers in Lempuing District, Ogan Komering llir Regency have not utilized rainfed rice fields for planting corn after planting rice. The purpose of this study was to determine the feasibility of cultivating BIMA 19-URI hybrid maize in rainfed rice fields in an effort to increase farmers' income. This activity was carried out in rainfed rice fields in the Sampurna Tani Group, Cahya Maju Village, Lempuing District, Ogan Komering llir Regency with an area of 1.5 ha in 2017 Constitutional Court, and involved 6 cooperator farmers. The corn variety used is Bima 19-URI. The results of the study indicated that the hybrid corn farming of Bima 19-URI variety in rainfed rice fields was financially feasible with an $R / C$ value of 1.9 . However, the $B / C$ yield $<1$, which is equal to 0.9 , which means that the economic benefits of hybrid maize farming are still relatively low. For that we need more effective efforts to achieve optimal productivity.
\end{abstract}

Keywords: Feasibility of farming, maize, rainfed

\section{ABSTRAK}

Provinsi Sumatera Selatan memiliki potensi dalam pengembangan usahatani jagung, namun petani di Kecamatan Lempuing, Kabupaten Ogan Komering llir belum memanfaatkan lahan sawah tadah hujan untuk ditanami jagung setelah penanamn padi. Adapun tujuan penelitian ini untuk mengetahui kelayakan usahatani jagung hibrida BIMA 19-URI di lahan sawah tadah hujan dalam upaya meningkatkan pendapatan petani. Kegiatan ini dilaksanakan di lahan sawah tadah hujan Kelompok Sampurna Tani Desa Cahya Maju Kecamatan Lempuing Kabupaten Ogan Komering llir dengan luasan 1,5 ha pada MK 2017, dan melibatkan 6 petani kooperator. Varietas jagung yang digunakan yaitu Bima 19-URI. Hasil pengkajian menunjukkan bahwa usahatani jagung hibrida varietas Bima 19-URI di lahan sawah tadah hujan secara finansial layak diusahakan dengan nilai $R / C$ 1,9. Namun hasil $B / C<1$, yaitu sebesar 0,9 yang berarti manfaat ekonomi usahatani jagung hibrida masih relatif rendah. Untuk itu diperlukan upaya yang lebih efektif untuk mencapai produktivitas yang optimal.

Kata kunci: Kelayakan usahatani, jagung, tadah hujan

\section{PENDAHULUAN}

Jagung mempunyai arti penting dalam pengembangan industri di Indonesia karena merupakan bahan baku untuk industri pangan maupun industri pakan ternak. Semakin berkembangnya industri pengolahan pangan di Indonesia maka kebutuhan akan jagung akan semakin meningkat pula (Badan Litbang Pertanian, 2007). Permintaan jagung yang semakin banyak maka diperlukan usaha ekstensifikasi dan intensifikasi, tetapi pada saat ini terjadi alih fungsi lahan untuk perkebunan, perumahan dan pembangunan industri sehingga usaha kedepan dengan peningkatan produktivitas menggunakan varietas unggul yang berdaya hasil tinggi. Soehendi dan Syahri (2013), mengemukakan salah satu permasalahan dalam pengembangan jagung adalah ketersediaan varietas unggul, karena varietas unggul memegang peranan dalam mendorong peningkatan produktivitas tanaman. Dikemukakan oleh Idris (2008) dalam Helmi dan Sembiring, (2013) penggunaan varietas unggul yang ditanam terus 
menerus akan mengalami perubahan antara lain kemurnian varietas dan reaksinya terhadap hama dan penyakit tertentu semakin menurun. Oleh karena itu diperlukan varietas unggul baru yang dapat menggantikan varietas yang biasa digunakan petani. Teknologi ini lebih aman dan lebih ramah lingkungan serta murah harganya bagi petani. Jagung dapat ditanam pada lahan kering, lahan sawah irigasi, lahan sawah tadah hujan, lahan lebak, dan lahan pasang surut dengan berbagai jenis tanah, berbagai tipe iklim dan ketinggian tempat 0 $2000 \mathrm{~m}$ dari permukaan laut (Zubachtirodin, et al., 2008)

Secara nasional luasan lahan sawah tadah hujan mencapai 2,1 juta ha sampai 2,6 juta ha dan sekitar 900.000 ha terdapat di Pulau Jawa, sehingga lahan sawah tadah hujan dapat menjadi alternatif dalam rangka mendukung ketahanan pangan (Aos dan Ruswandi, 2012). Sumatera Selatan mempunyai sumberdaya yang cukup potensial dalam pengembangan jagung, baik perluasan areal (ektensifikasi) maupun peningkatan produksi (intensifikasi), mengingat semua daerah (kabupaten/kota) merupakan daerah penghasil jagung. Luas sawah tadah hujan di Sumsel ialah 96.885 ha atau $12,5 \%$ dari luas lahan sawah (774.502 ha) (BPS Provinsi Sumatera Selatan, 2015). Produktivitas jagung Sumatera Selatan tahun 2014 baru mencapai 6,01 ton/ha (BPS Indonesia, 2014), sementara potensi hasil jagung hibrida mencapai 9-13 ton/ha pipilan kering. Rendahnya disebabkan oleh berbagai faktor antara lain, teknologi bercocok tanam yang masih kurang baik, kesiapan dan keterampilan petani jagung yang masih kurang, penyediaan sarana produksi yang masih belum tepat, kurangnya pemodalan petani jagung untuk menyediakan sarana produksi.

Kecamatan Lempuing merupakan salah satu Kecamatan di Kabupaten Ogan Komering llir yang terdiri dari 19 Desa. Luas wilayah Kecamatan Lempuing adalah $25.570,5$ ha terdiri dari luas lahan kering $15.137,5$ ha, sawah irigasi 650 ha, sawah tadah hujan 9.397 ha, kolam/empang 21 ha, perairan umum/rawa 365 ha. Lahan ini terletak pada ketinggian sekitar 8 - $16 \mathrm{~m}$ dpl. pH tanah 4,0 - 5,5. Bulan basah terjadi pada bulan Oktober-Maret dan bulan kering terjadi pada bulan April-September (Balai Penyuluhan Pertanian Cahya Maju, 2016).

Pada umumnya petani di Kecamatan Lempuing Kabupaten Ogan Komering llir belum terbiasa menanam jagung setelah panen padi kedua (IP200). Sehingga petani membiarkan lahan sawahnya diberakan hingga 3-4 bulan, padahal lahan yang diusahakannya termasuk lahan produktif bila diusahakan dengan menanam jagung ataupun palawija lainnya maka akan mendapatkan tambahan penghasilan. Sehubungan dengan program yang telah dicanangkan oleh pemerintah yaitu strategi peningkatan produksi jagung berkelanjutan yang berbasis kawasan, maka melalui Balai Pengkajian Teknologi Pertanian Sumatera Selatan memperagakan varietas unggul baru jagung dalam mendukung program pengembangan kawasan areal pertanaman jagung di Sumatera Selatan. Adapun tujuan penelitian ini adalah untuk mengetahui kelayakan usahatani jagung hibrida BIMA 19-URI di lahan sawah tadah hujan dalam upaya meningkatkan pendapatan petani.

\section{METODE PENELITIAN}

Pendampingan budidaya tanaman jagung setelah tanam padi (IP 200) di Kelompok Sampurna Tani Desa Cahya Maju Kecamatan Lempuing agroekosistem sawah tadah hujan Kabupaten Ogan Komering llir luasan 1,5 ha pada akhir Bulan Agustus 2017 (MK 2017), dengan melibatkan 6 petani kooperator. Varietas jagung yang digunakan yaitu Bima 19-URI sedangkan petani menggunakan varietas Pioneer-35. Inovasi teknologi yang diintroduksikan pada kegiatan ini disajikan pada Tabel 1. Data yang dikumpulkan meliputi: tinggi tanaman, jumlah daun, tinggi letak tongkol, panjang tongkol, lilit tongkol dan produksi. Data tersebut dianalisis dengan uji persamaan nilai tengah (uji t) menggunakan program SPSS. Analisis yang digunakan untuk mengetahui kelayakan usaha dengan analisis nisbah atau rasio penerimaan terhadap biaya (R/C) (Hendrayana, 2016). Formula yang digunakan:

$\frac{R}{C}=\frac{T R}{T C}=\frac{(Q . p Q)}{\left(\sum_{i=1}^{n_{i}} X_{i} p X_{i}\right)}$

Kemudian dilanjutkan dengan analisis nisbah atau rasio keuntungan terhadap biaya $(B / C)$, dengan rumus:

$$
\frac{B}{C}=\frac{T R-T C}{T C} \frac{\left(Q \cdot p Q-\sum_{i=1}^{n_{i}} X_{i} \cdot p X_{i}\right)}{\left(\sum_{i=1}^{n_{i}} X_{i} \cdot p X_{i}\right)}
$$

$$
\begin{aligned}
& \text { Keterangan : } \\
& \begin{array}{ll}
\text { TR } & =\text { Total } \\
\text { Revenue }=\text { Penerimaan }(\mathrm{Rp}) \\
\mathrm{B} & =\text { Benefit }(\text { manfaat }) \\
\mathrm{Q} & =\text { Quantum }=\text { jumlah produksi }(\mathrm{kg}) \\
\mathrm{pQ} & =\text { harga produksi }(\mathrm{Rp} / \mathrm{kg})
\end{array}
\end{aligned}
$$


TC $=$ Total Cost $=$ Biaya pembelian input $(R p) \quad p X_{i} \quad=$ Harga input $X$ ke $i(i=1,2,3, \ldots n)$

$X_{i} \quad=$ Jenis input $X$ ke $i(i=1,2,3, \ldots n)$

Tabel 1. Komponen teknologi jagung hibrida Bima 19-URI di Desa Cahya Maju, Kecamatan Lempuing Kab.OKI 2017

\begin{tabular}{|c|c|}
\hline Komponen teknologi & Keterangan \\
\hline Varietas hibrida & Bima 19-URI \\
\hline Kebutuhan benih & $15-20 \mathrm{~kg} / \mathrm{ha}$ \\
\hline Perlakuan benih & $\begin{array}{l}1 \mathrm{~kg} \text { benih dicampur dengan } 2 \mathrm{~g} \text { ridomil yang dilarutkan dalam } 10 \\
\mathrm{ml} \text { air. }\end{array}$ \\
\hline Pembersihan lahan & Herbisida \\
\hline Pengolahan lahan & Tanah dibajak dan garu \\
\hline Buat parit & lebar $40 \mathrm{~cm}$, dalam $20 \mathrm{~cm}$ \\
\hline Pengapuran (Dolomit/kaptan) & Diberikan bersamaan pengolahan tanah, takaran 1 ton/ha \\
\hline Penanaman & $\begin{array}{l}\text { Tanam dengan cara ditugal dengan kedalaman 3-5 } \mathrm{cm} \text {. Penanaman } \\
\text { dilakukan dengan cara mengisi lubang tanam dengan } 1-2 \text { benih } \\
\text { jagung disertai dengan furadan } 1 \mathrm{~g} \text { tiap lubang lalu ditutup kembali } \\
\text { dengan tanah }\end{array}$ \\
\hline Jarak tanam & $70 \mathrm{~cm} \times 20 \mathrm{~cm}$ \\
\hline Kebutuhan pupuk organic & Pupuk petrogenik 1 ton/ha \\
\hline Kebutuhan pupuk an organic & $350 \mathrm{~kg}$ urea, $200 \mathrm{~kg} \mathrm{SP}-36$ dan $100 \mathrm{~kg} \mathrm{KCl} / \mathrm{ha}$ \\
\hline Takaran pupuk dasar (pemupukan 1) & $\begin{array}{l}200 \mathrm{~kg} \text { Urea }+200 \mathrm{~kg} \mathrm{SP}-36+50 \mathrm{~kg} \mathrm{KCl} / \mathrm{ha}+1 \text { ton/ha petrogenik } \\
\text { pada umur } 7-10 \text { hari setelah tanam }\end{array}$ \\
\hline $\begin{array}{l}\text { Takaran pupuk susulan (pemupukan } \\
\text { ke 2) }\end{array}$ & $150 \mathrm{~kg}$ Urea + $50 \mathrm{~kg} \mathrm{KCl} / \mathrm{ha}$ pada umur $28-30$ hari setelah tanam \\
\hline Cara pemupukan & $\begin{array}{l}\text { Pupuk dimasukkan dalam lubang tugal dengan kedalaman 7-10 dan } \\
\text { jarak } 10-15 \mathrm{~cm} \text { dari tanaman atau secara larikan diantara tanaman } \\
\text { jagung. Kemudian lubang ditutup kembali }\end{array}$ \\
\hline Penyulaman & $\begin{array}{l}\text { Penyulaman dilakukan pada tanaman yang mati dengan umur yang } \\
\text { sama atau bibit }\end{array}$ \\
\hline Penyiangan & $\begin{array}{l}\text { Dilakukan } 2 \text { kali yaitu pada umur } 15 \text { HST dan 28-30 HST sebelum } \\
\text { pemupukan ke dua. }\end{array}$ \\
\hline Pengairan & Curah hujan \\
\hline Pengendalian hama dan penyakit & Pengendalian hama dan penyakit terpadu \\
\hline Panen & Panen dapat dilakukan secara manual \\
\hline Pasca panen & $\begin{array}{l}\text { Jagung dikupas, dijemur secara alami dan dipipil dengan mesin } \\
\text { perontok }\end{array}$ \\
\hline
\end{tabular}

HASIL DAN PEMBAHASAN

\section{Pertumbuhan Jagung.}

Demplot tanaman jagung dengan menampilkan varietas Bima 19-URI ditanam pada akhir bulan Agustus 2017 di Desa Cahya Maju Kecamatan Lempuing Kabupaten Ogan Komering llir (OKI). Pertumbuhan dan produksi jagung hibrida Bima 19-URI (Introduksi) dan Pioneer-35 (eksisting) dapat dilihat pada Tabel 2. 
Tabel 2. Pengamatan pertumbuhan dan produksi jagung hibrida di Desa Cahya Maju Kecamatan Lempuing Kab.OKI, 2017

\begin{tabular}{|c|c|c|}
\hline Parameter & Bima 19-URI (Introduksi) & Pioneer-35 (eksisting) \\
\hline Tinggi tanaman $(\mathrm{cm})$ & 256 tn & 255 \\
\hline Jlh daun (helai) & $11,3^{* *}$ & 10,6 \\
\hline Tinggi letak tongkol (cm) & $114^{* *}$ & 92,4 \\
\hline Panjang tongkol $(\mathrm{cm})$ & 20,4 ** & 18,4 \\
\hline Lilit tongkol (cm) & 15,5 tn & 15,0 \\
\hline $\begin{array}{l}\text { Produksi konversi per ha pipilan kering } \\
\text { (ton/ha) }\end{array}$ & $7,2^{\text {** }}$ & 5,8 \\
\hline
\end{tabular}

Keterangan: $\mathrm{Tn}=$ Tidak beda nyata ${ }^{* *}=$ Berbeda sangat nyata

Hasil analisis dengan uji T menunjukkan pertumbuhan dan produksi tanaman jagung varietas Bima 19-URI berbeda sangat nyata dengan varietas Pioneer 35 terhadap jumlah daun, tinggi letak tongkol, panjang tongkol, dan produksi kecuali tinggi tanaman dan lilit tongkol. Hal ini disebabkan varietas Bima-19 URI yang didesiminasikan kepada petani menerapkan komponen teknologi yang dianjurkan seperti dosis pupuk urea, SP-36 dan $\mathrm{KCl} /$ ha lebih banyak, pemberian kapur dolomite karena $\mathrm{pH}$ tanah agak masam, dan pemberian pupuk dimasukkan dalam lubang lalu ditutup dengan tanah (ditugal). Sedangkan petani menggunakan pupuk NPK Ponska (15:15:15) dalam jumlah sedikit, tanah tidak diberi kapur dan cara pemberian pupuk disebar. Dikatakan oleh Erselia et al. (2017), tanah dengan $\mathrm{pH}$ dibawah 6,5 menyebabkan unsur hara fosfor $(P)$ tidak tersedia karena terikat dengan $\mathrm{Al}$ dan $\mathrm{Fe}$ membentuk senyawa yang tidak larut. Suntoro dan Puji Astuti (2014) mengemukakan dengan pemberian pupuk $\mathrm{N}, \mathrm{P}$ dan $\mathrm{K}$ yang cukup dapat meningkatkan ketersediaan unsur hara $\mathrm{N}, \mathrm{P}$ dan $\mathrm{K}$ untuk diserap tanaman sehingga memicu pertumbuhan dan perkembangan tanaman. Pemberian pupuk dengan cara disebar tidak efektif karena akan tercuci oleh air hujan, dan unsur nitrogen akan menguap atau hilang sehingga tanaman tidak dapat memanfaatkan unsur tersebut. Varietas Pioneer -35 merupakan varietas yang ditanam oleh petani dengan input sesuai kemampuan petani sehingga produksinya lebih rendah yaitu 5,8 ton pipilan kering/ha sedangkan varietas Bima 19 URI sebesar 7,2 ton pipilan kering/ha (kadar air 15\%).

Berdasarkan deskripsi dari varietas Bima 19 URI bahwa tinggi tanaman, jumlah daun, tinggi letak tongkol, panjang tongkol, lilit tongkol melebihi dari deskripsi varietas Bima 19-URI dimana tinggi tanaman rata-rata $256 \mathrm{~cm}$, jumlah daun rata-rata 11,3 helai, tinggi letak tongkol rata-rata $114 \mathrm{~cm}$, panjang tongkol $20,4 \mathrm{~cm}$, lilit tongkol rata-rata 15,5 $\mathrm{cm}$ kecuali produksi hanya mencapai 7,2 ton pipilan kering/ha masih jauh dari rata-rata hasil varietas Bima 19-URI, yaitu 9,3 ton/ha (Jamil et al., 2016). Pertumbuhan dan produksi jagung dapat meningkat bila didukung oleh kondisi lingkungan diantaranya cukup penyinaran atau cahaya, air dan unsur hara (Sirappa dan Rozak, 2010) dalam Asroh et al. (2015). Menurut Agrita (2012) dalam Wahyudin et al. (2016) bahwa kondisi lingkungan yang paling berpengaruh ialah temperatur pada saat pertumbuhan dan dapat mempengaruhi ukuran biji maksimum, untuk membentuk ukuran biji maksimum diperlukan suhu rata-rata $25^{\circ} \mathrm{C}$. Semakin baik kondisi lingkungan tanaman tumbuh maka tanaman akan dapat mengekspresikan sifat genotifnya dengan baik sehingga tanaman dapat tumbuh secara normal.

Keunggulan jagung Bima 19-URI ini antara lain tahan terhadap penyakit bulai, tahan penyakit karat dan hawar daun, toleran terhadap kekeringan, tahan rebah akar/batang serta stay green. Keragaan fisik tanaman Bima 19-URI disukai oleh petani karena batangnya yang kokoh, besar dan berdaun lebar serta lebih lunak sehingga sangat disukai ternak sapi. (BPTP Kalimantan Selatan, 2015).

\section{Kelayakan Usahatani Jagung.}

Analisis usahatani budidaya tanaman jagung hibrida Bima 19-URI di Desa Cahya Maju, Kecamatan Lempuing ,Kabupaten Ogan Komering llir dapat dilihat pada Tabel 3. 
Tabel 3. Struktur Biaya dan Pendapatan Usahatani Jagung Bima 19-URIdi Desa Cahya Maju, Kecamatan Lempuing Kabupaten OKI, MK 2017.

\begin{tabular}{|c|c|c|c|}
\hline No & Uraian & Volume & Nilai (Rp) \\
\hline \multirow[t]{9}{*}{$A$} & Biaya Saprodi (Rp) & & \\
\hline & 1.Benih hibrida & $20 \mathrm{~kg}$ & 1.000 .000 \\
\hline & 2. Urea & $350 \mathrm{~kg}$ & 735.000 \\
\hline & 3. SP-36 & $200 \mathrm{~kg}$ & 520.000 \\
\hline & 4. $\mathrm{KCl}$ & $100 \mathrm{~kg}$ & 580.000 \\
\hline & 5. Kapur dolomit & $1.000 \mathrm{~kg}$ & 750.000 \\
\hline & 6.Pupuk organik & $1.000 \mathrm{~kg}$ & 1.000 .000 \\
\hline & 7.Pestisida & & 1.190 .000 \\
\hline & Jumlah Biaya Saprodi & & 5.775 .000 \\
\hline \multirow[t]{2}{*}{ B } & Biaya Tenaga .Kerja (Rp) & & 7.200 .000 \\
\hline & Total Biaya $(A+B)$ & & 12.975 .000 \\
\hline \multirow[t]{6}{*}{ C } & Hasil $(\mathrm{kg})$ pipilan kering/ha & 7200 & \\
\hline & Harga pipilan kering (RP/kg) & 3500 & \\
\hline & Penerimaan (Rp) & & 25.200 .000 \\
\hline & Pendapatan (Rp) & & 12.225 .000 \\
\hline & $\mathrm{R} / \mathrm{C}$ & & 1,9 \\
\hline & $\mathrm{B} / \mathrm{C}$ & & 0,9 \\
\hline
\end{tabular}

Keterangan : Upahan harian Rp 80.000

Analisis usahatani dipengaruhi oleh produksi, biaya usahatani, harga jual dan harga beli dari sarana produksi yang sangat mempengaruhi pendapatan/keuntungan usahatani

Produksi jagung ditentukan oleh penggunaan input seperti benih, pupuk, pestisida dan cara tanam. Biaya usahatani merupakan ukuran nilai sumber daya yang harus dikorbankan guna mendapatkan keuntungan (Boediono, 1990 dalam Palobo, 2019). Besarnya pendapatan dapat diketahui dengan cara mengetahui terlebih dahulu total dari penerimaan yang diperoleh kemudian dikurangi dengan total biaya yang dikeluarkan untuk kegiatan usahatani. Pendapatan dalam usahatani dikatakan menguntungkan bila penerimaan yang diperoleh lebih besar dari biaya yang dikeluarkan oleh petani. Hasil analisis usahatani jagung varietas Bima 19 URI menunjukkan bahwa penerimaan dan pendapatan dapat dilihat pada Tabel 3. Penerimaan yang diperoleh sebesar Rp 25.200.000 dan pendapatan $\mathrm{Rp}$ 12.225.000 dengan $\mathrm{RC}$ ratio 1,9 artinya bahwa setiap pengeluaran biaya sebesar Rp 1.000 terhadap input yang diberikan akan memperoleh penerimaan sebesar $\mathrm{Rp} 1.900$ maka usahatani dengan menggunakan varietas Bima 19 URI layak untuk dikembangkan.
Hasil perhitungan $\mathrm{BC}$ ratio usahatani jagung hibrida Bima 19-URI hanya 0,9. Menurut Hendrayana (2016), apabila $B / C<1$ artinya manfaat usahatani jagung belum optimal.

\section{Preferensi petani terhadap varietas}

Berdasarkan hasil wawancara dan pengamatan langsung oleh petani koperator terhadap varietas Bima-19 dan Pioneer-35, sebagian besar petani sekitar 90\% memilih Bima 19 untuk dikembangkan. Alasan dari petani memilih Bima-19 yaitu memiliki umur genjah, tongkol besar dan seragam, tongkol lebih panjang, tahan kekurangan air, dan tahan rebah.

\section{KESIMPULAN}

Dari uraian hasil dan pembahasan dari kajian dapat dapat disimpulkan bahwa penampilan jagung hibrida varietas Bima 19-URI dari pertumbuhan sampai produksi lebih unggul dibandingkan varietas Pioneer-35 dengan peningkatan produksi 1,6 ton pipilan kering/ha.

Usahatani jagung hibrida varietas Bima 19URI di Desa Cahya Maju, Kecamatan Lempuing, Kabupaten Ogan Komering Ilir layak secara finansial, akan tetapi manfaat ekonomi masih relatif rendah. 


\section{DAFTAR PUSTAKA}

Aos dan Ahim Ruswandi. 2012. Optimasi pemberian takaran pupuk organik dan jumlah benih terhadap pertumbuhan serta hasil tanaman padi pada sawah tadah hujan di Sumedang. Dalam Djoko, P., A. Ratriyanto, J. Sutrisno, A. Wibowo, Widiyanto dan $\mathrm{H}$. Ihsaniyati (Eds). Prosiding Seminar Nasional Fakultas Pertanian Universitas Sebelas Maret Surakarta. 678 hal.

Asroh A, Nurlaili dan Fahrulrozi. 2015. Produksi tanaman jagung (Zea mays $L$ ) pada berbagai jarak tanam di tanah ultisol. Jurnal Lahan Sub Optimal 4 (1):66-70.

Badan Pusat Statistik Provinsi Sumsel. 2015. Luas lahan menurut penggunaan. Badan Pusat Statistik Provinsi Sumatera Selatan, Palembang.

Badan Penelitian dan Pengembangan Pertanian. 2007. Teknik Produksi dan Pengembangan Jagung. Jakarta.

Badan Pusat Statistik Provinsi Sumatera Selatan. 2014. Sumtera Selatan Dalam Angka. Provinsi Sumatera Selatan.

Balai Pengkajian Teknologi Pertanian Kalimantan Selatan. 2015. Bima-19 uri, jagung unggulan masa depan. (https://www.jitunews.com/read/11793/bima-19uri-jagung-unggulan-masa-depan).Diakses 25 Maret 2019

Balai Penyuluhan Pertanian. Diakses Cahya Maju. 2016. Programa Penyuluhan Pertanian. Balai Penyuluhan Pertanian Cahya Maju.

Erselia I, DW Respatie, R Rogomulyo. 2017. Pengaruh takaran kombinasi pupuk NPK dan pupuk organik alami diperkaya mikroba fungsional terhadap pertumbuhan dan hasil jagung. Jurnal Vegetalita 6 (4): 28-40.

Helmi dan Tuah Sembiring. 2013. Penampilan produktivitas beberapa galur dan varietas jagung di Kabupaten Simalungun. Prosiding Seminar Nasional Buku 1 Balai Besar pengkajian dan Pengembangan Pertanian, Bogor.

Hendrayana, R. 2016. Analisis Data Pengkajian. IAARD PRESS. Jakarta.

Jamil A, MJ Mejaya, RH Praptana, NA Subekti, M Aqil, A Musaddad dan F Putri. 2016. Deskripsi varietas unggul tanaman pangan 2010-2016. Kementerian Pertanian.152 hal.

Palobo, F, H.Masbaitubun, S.Tirajoh. 2019. Analisis kelayakan usahatani jagung hibrida pada lahan kering di Merauke, Papua. Jurnal SEPA 16 (1):1-10

Soehendi dan Syahri. 2013. Potensi Pengembangan jagung di Sumatera Selatan. Jurnal lahan Suboptimal, 2(1) April 2013.Hal.81-92

Suntoro, Puji Astuti. 2014. Pengaruh waktu pemberian dan dosis pupuk NPK Pelangi terhadap pertumbuahn tanaman jagung manis varietas sweet boys. Jurnal AGRIFOR XIII (2):213-222.

Wahyudin, A, Ruminta dan S.A.Nursarifah. 2016. Pertumbuhan dan hasil tanaman jagung toleran herbisia akibat pemberian berbagai dosis herbsida kalium glifosat. Jurnal Kultivasi 15 (2): 86-91.

Zubachtirodin, M.S Pabbage dan Subandi. 2008. Wilayah produksi dan potensi pengembangan jagung. Jagung : Teknik produksi dan pengembangan. Balai Penelitian Tanaman Serealia Maros. 